\title{
Gas Chromatographic and Spectrophotometric Determination of Diclofenac Sodium, Ibuprofen, and Mefenamic Acid in Urine and Blood Samples
}

\section{Gaz Kromatografisi ve Spektrofotometri Yöntemleriyle İdrar ve Kan Örneklerinde Diklofenak Sodyum, İbuprofen ve Mefenamik Asit Tayini}

 \\ 1University of Sindh National Center of Excellence in Analytical Chemistry, Jamshoro, Pakistan \\ ZUniversity of Sindh Institute of Advanced Research Studies in Chemical Sciences, Jamshoro, Pakistan
}

\begin{abstract}
Objectives: Non-steroidal anti-inflammatory drugs (NSAIDs) are widely used for the treatment of acute to chronic pain. A simple, fast, and reliable gas chromatographic (GC) method with flame ionization detection has been developed for the determination of NSAIDs such as diclofenac sodium, ibuprofen, and mefenamic acid after derivatization with ethyl chloroformate.

Materials and Methods: The GC conditions were optimized as elution from a DB- 1 column ( $30 \mathrm{m \times 0.32} \mathrm{mm} \mathrm{id)} \mathrm{at} \mathrm{column} \mathrm{temperature} 150{ }^{\circ} \mathrm{C}$ for 3 min, followed by a heating rate of $20^{\circ} \mathrm{C} / \mathrm{min}$ up to $280{ }^{\circ} \mathrm{C}$ and a hold time of $5 \mathrm{~min}$. The nitrogen flow rate was $2.5 \mathrm{~mL} / \mathrm{min}$. For spectrophotometric studies, the absorbance was measured against methanol at a wavelength of $200-500 \mathrm{~nm}$.

Results: The calibration curves were linear within $2-10 \mu \mathrm{g} / \mathrm{mL}$ with limits of detection of $0.4-0.6 \mu \mathrm{g} / \mathrm{mL}$ of each drug. The derivatization elution, separation, and quantitation were repeatable $(n=3)$ with relative standard deviation (RSD) within $3.9 \%$. The method was applied for the analysis of the drugs from pharmaceutical formulations and the results of the analysis agreed with labeled values with RSDs within 0.5-3.9\%. The results were also confirmed by standard addition method. The percent recovery was calculated with spiked deproteinized human blood serum and urine samples and \% recovery of the drugs was obtained within $96-98 \%$ with RSDs within $3.1 \%$.

Conclusion: The validated method proved its ability for the assay of NSAIDs in bulk and dosage form in a short analysis time. The method was also useful for the analysis of biological samples.
\end{abstract}

Key words: NSAIDs, GC analysis, derivatization of NSAIDs

ÖZ

Amaç: Non-steroid anti-enflamatuvar ilaçlar (NSAID) akut ve kronik ağrı tedavisinde yaygın olarak kullanılmaktadır. Etil kloroformat ile türevlendirme işlemini takiben diklofenak sodyum, ibuprofen ve mefenamik asit gibi NSAID'lerin belirlenmesi için alev iyonizasyon dedektörlü basit, hızlı ve güvenilir bir gaz kromatografisi (GC) yöntemi geliștirilmiștir.

Gereç ve Yöntemler: GC koșulları, 3 dakika boyunca $150{ }^{\circ} \mathrm{C}$ kolon sıcaklığında DB-1 kolonundan (30 m x 0,32 mm id) elüsyon, ardından $280{ }^{\circ} \mathrm{C}$ ye kadar $20^{\circ} \mathrm{C} /$ dak olacak şekilde ısıtma ve 5 dakika bekleme olarak optimize edilmiştir. Azot akış hızı 2,5 mL/dk olarak ayarlanmıştır. Spektrofotometrik çalışmalar için absorbans, 200-500 nm dalga boyunda metanole karşı ölçülmüştür.

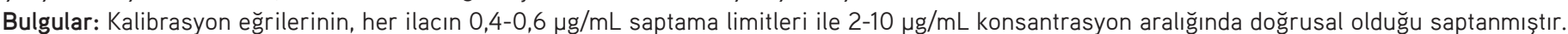
Türetme elüsyonunun, ayırmanın ve miktar tayininin, \%3,9'luk bağıl standart sapma ile tekrarlanabilir ( $n=3$ ) olduğu bulunmuștur. Yöntem, farmasötik formülasyonlardan elde edilen ilaçların analizi için uygulandı ve analiz sonuçları, RSD'ler ile \%0,5-3,9 arasında etiketli değerlerle uyumluydu. Sonuçlar ayrıca standart ekleme yöntemi ile doğrulanmıştır. Geri kazanım yüzdesi, deproteinize edilmiş insan serumu ve idrar örnekleri ile hesaplandı ve ilaçların geri kazanım yüzdesi, \%3,1 içindeki RSD'ler ile \%96-98 içinde elde edildi.

Sonuç: Valide edilmiş bu yöntemin kısa analiz süresi içinde bulk ve dozaj formundaki NSAID’leri analiz edebildiği doğrulanmıştır. Yöntemin, biyolojik numunelerin analizi için de yararlı olduğu tespit edilmiştir.

Anahtar kelimeler: NSAID'ler, GC analizi, NSAID'lerin türevlendirilmesi

*Correspondence: E-mail: +923332760143, Phone: ambersolangi@gmail.com ORCID-ID: orcid.org/0000-0002-3852-1245

Received: 31.01.2019, Accepted: 21.03.2019

-Turk J Pharm Sci, Published by Galenos Publishing House. 


\section{INTRODUCTION}

Drugs such as diclofenac sodium, ibuprofen, and mefenamic acid are commonly used all over the world. These drugs belong to the class of non-steroidal anti-inflammatory drugs (NSAIDs), which are used for antipyretic, analgesic, and anti-inflammatory purposes.,2 These types of drugs are generally used as pain killers. People use NSAIDs without a prescription from a doctor because of the low possibility of side effects. These types of drugs are also very effective for people with arthritis or rheumatic diseases. Pregnant women may use NSAIDs if prescribed by their physicians. NSAIDs can cause several side effects if used for a long time such as gastrointestinal bleeding, intestinal ulceration, aplastic anemia, agranulocytosis, kidney damage, and cardiovascular risk. $^{3}$ Diclofenac sodium [2-(2-6-diclorophenyl) aminophenyl benzoic acid], ibuprofen (Rs)-2[4-(2-methylpropyl phenyl) propanoic acid], and mefenamic acid [2-(2,3-dimethylphenyl) aminophenylbenzoic acid] are NSAIDs and are commonly used for antipyretic, analgesic, and anti-inflammatory purposes. They are also used for the treatment of rheumatic disorders, pain, and fever. ${ }^{4,5}$<smiles>CC(C)Cc1ccc(C(C)C(=O)O)cc1</smiles>

Ibuprofen<smiles>O=C(Cc1ccccc1Nc1c(Cl)cccc1Cl)O[Na]</smiles>

Diclofenac sodium

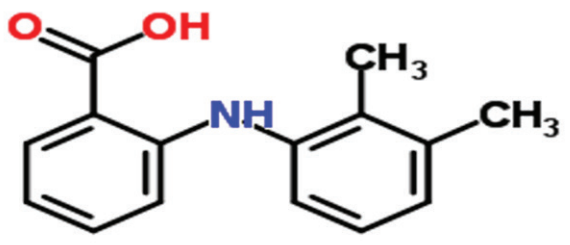

Mefenamic acid

Many methods have been reported for the determination of diclofenac sodium, ibuprofen, and mefenamic acid individually and in mixtures. ${ }^{6}$ Diclofenac salts have been determined by spectrophotometry, ${ }^{7}$ spectrofluorometry, ${ }^{8}$ thin layer high performance liquid chromatography (HPLC), ${ }^{9}$ and gas chromatography $(\mathrm{GC})^{10}$ in a wide variety of samples. Similarly, mefenamic acid has been analyzed by spectrophotometry, spectrofluorometry, ${ }^{12}$ electrophoresis, ${ }^{13}$ and chromatography. ${ }^{14}$ In pharmaceutical preparations and biological fluids for the simultaneous determination of NSAIDs chromatographic (GC, HPLC) procedures are used. ${ }^{15} \mathrm{GC}$ is easy to perform with high resolution efficiency and does not involve the problem of solvents used. The acidic compounds diclofenac sodium, mefenamic acid, and ibuprofen are difficult to elute from the GC column and require derivatization before their analysis. ${ }^{16}$ GC derivatization can be defined as the procedure used to modify analyte functionality to make it suitable for GC separation. Derivatization enables an extremely polar substance to become quite volatile so that it can be easily eluted at sensible temperatures. ${ }^{17}$ The compounds with attached functional groups, for instance $-\mathrm{SH},-\mathrm{OH},-\mathrm{NH}$, and $-\mathrm{COOH}$, have importance for $\mathrm{GC}$ analysis because these groups have a tendency to undergo hydrogen bonding. ${ }^{18,19}$ These hydrogen bond formations have effects on the volatility, thermal stability, and interaction of the analyte with the column packing material.

The present work examineed the less expensive ethyl chloroformate (ECF) as a derivatizating reagent for GC-flame ionization detector (FID) determination of diclofenac sodium, ibuprofen, and mefenamic acid for an aqueous medium from a pharmaceutical preparation and biological fluids. In this study, we developed a new GC-FID method that is easy, cheap, fast, selective, and reliable for the determination of NSAIDs. Furthermore, spectrophotometric studies were also performed to optimize all the parameters with and without derivatization for all NSAIDs. The developed method shows better limits of detection (LOD) and limits of quantitation (LOQ) with a good regression coefficient and was applied to real blood and urine samples.

\section{MATERIALS AND METHODS}

\section{Chemical and reagents}

All the chemicals used were GR or AR grade. ECF (Fluka, Buchs, Switzerland), methanol, chloroform, acetonitrile (Fluka, Buchs, Switzerland), and pyridine (E-Merck, Darmstadt, Germany) were used. Pure standard of ibuprofen was obtained from Abbott Laboratories, Karachi, Pakistan, and mefenamic acid from Pfizer Laboratories Karachi, Pakistan, as a gift for the research. Diclofenac sodium was obtained from Sigma Aldrich (St. Louis, MO, USA). Ammonium chloride, potassium chloride, boric acid, sodium tetraborate, sodium carbonate, sodium bicarbonate, acetic acetate, ammonium acetate, ammonia solution, and hydrochloric acid (37\%) for the preparation of buffer solutions were obtained from E-Merck, Darmstadt, Germany.

Buffer solutions $(0.1 \mathrm{M})$ of $\mathrm{pH} 1-12$ with 0.5 unit interval were prepared from the following: potassium chloride adjusted with hydrochloric acid ( $\mathrm{pH} 1-2)$, acetic acid-sodium acetate $(\mathrm{pH} 3-6)$, ammonium acetate $(\mathrm{pH} 7)$, boric acid-sodium tetraborate $(\mathrm{pH}$ 7.5-8.5), ammonium chloride-ammonia ( $\mathrm{pH} 10$ ), and potassium chloride-potassium hydroxide ( $\mathrm{pH}$ 11-12). Standard solutions of ibuprofen, diclofenac sodium, and mefenamic acid containing 1 $\mathrm{mg} / \mathrm{mL}$ each were prepared separately in methanol:water (1:1 $\mathrm{v} / \mathrm{v}$ ). Further solutions were prepared by appropriate dilutions. 


\section{Instrumentation}

All $\mathrm{pH}$ measurements were made with an Orion star $\mathrm{pH}$ meter (Orion Research Inc., Boston, MA, USA). The spectrophotometric studies were carried out on a Hitachi 220 double beam spectrophotometer [Hitachi (Pvt) Ltd, Tokyo, Japan] with dual quartz cuvettes. Gas chromatographic studies were carried out on an Agilent 6890 model gas chromatograph (Agilent Technologies, CA, USA) with a FID, split injector, hydrogen generator $\mathrm{H}_{2}-90$ (Parker Hannifin, Haverhill, MA, USA), pure nitrogen (British Oxygen Company, Karachi, Pakistan), and a computer with Chemostation software. A capillary column, DB-1 (30 m x $0.32 \mathrm{~mm}$ id), with film thickness $0.25 \mu \mathrm{m}$ (J.W. Scientific GC column, Willington, NC, USA) was used throughout the study.

\section{Statistical analysis}

All results were statistically analyzed and repeated 3 times. The $\%$ error, \% relative standard deviation (RSD), and regression coefficient were calculated using SPSS 16.0.

\section{Spectrophotometric procedure without derivatization}

For the spectrophotometric study, stock solutions containing $1 \mathrm{mg} / \mathrm{mL}$ were prepared in methanol in a $25-\mathrm{mL}$ volumetric flask. The solutions were appropriately diluted to $10 \mu \mathrm{g} / \mathrm{mL}$ for ibuprofen, mefenamic acid, and diclofenac sodium separately in a $10-\mathrm{mL}$ volumetric flask. The solutions were well mixed, and the absorbance was measured against methanol on a spectrophotometer (Hitachi 220) at a wavelength of 200-400 $\mathrm{nm}$. The maximum response was obtained at 240,260, and $300 \mathrm{~nm}$ for ibuprofen, mefenamic acid, and diclofenac sodium, respectively.

\section{Spectrophotometric procedure with derivatization}

For the spectrophotometric study stock solutions containing $1 \mathrm{mg} / \mathrm{mL}$ were prepared for ibuprofen, mefenamic acid, and diclofenac sodium separately and were further diluted to $10 \mu \mathrm{g} / \mathrm{mL}$ in methanol. The solution of $1 \mathrm{~mL}$ each of $100 \mu \mathrm{g} /$ $\mathrm{mL}$ ibuprofen, mefenamic acid, and diclofenac sodium was separately transferred into a $10-\mathrm{mL}$ volumetric flask and $(0.5$ $\mathrm{mL})$ solvent system of pyridine:methanol:acetonitrile:water $(8: 42: 8: 42 \mathrm{v} / \mathrm{v})$ and $(0.5 \mathrm{~mL})$ buffer of solution $\mathrm{pH} 9$ and $(0.4$ $\mathrm{mL}$ ) ECF were added and the contents were sonicated for 20 min at $30{ }^{\circ} \mathrm{C}$ room temperature. Then methanol was added up to the mark in a $10-\mathrm{mL}$ volumetric flask, the solutions were mixed, and the absorbance was measured against the reagent blank on a spectrophotometer at a wavelength of 200-400 nm. The maximum responses were obtained at 350,310 , and $350 \mathrm{~nm}$ for ibuprofen, diclofenac sodium, and mefenamic acid, respectively. The reagent blank was prepared with $1 \mathrm{~mL}$ of methanol and following the same procedure without addition of the analyte.

\section{Gas chromatographic procedure}

The solutions (0.2-1.0 mL) containing $10 \mu \mathrm{g} / \mathrm{mL}$ ibuprofen, mefenamic acid, and diclofenac sodium separately or in mixture were transferred to well stoppered test tubes. To the solution were added methanol:water:acetonitrile:pyridine (42:42:8:8 $\mathrm{v} / \mathrm{v})(0.5 \mathrm{~mL})$ solvent, carbonate buffer solution of $\mathrm{pH} 9(0.5$ $\mathrm{mL})$, and ECF $(0.4 \mathrm{~mL})$ and the contents were sonicated at room temperature $\left(30{ }^{\circ} \mathrm{C}\right)$ for $15 \mathrm{~min}$. Chloroform $(0.5 \mathrm{~mL})$ was added and the contents were mixed well. The layers were allowed to separate. The calculated volume of $0.5 \mathrm{~mL}$ from the organic layer was pipetted out into a screw capped sample vial. The solution ( $1 \mu \mathrm{L}$ ) was injected into the $\mathrm{GC}$ instrument at an initial column temperature of $150{ }^{\circ} \mathrm{C}$ for 3.0 min with a heating rate of $20{ }^{\circ} \mathrm{C} / \mathrm{min}$ up to $280{ }^{\circ} \mathrm{C}$. The nitrogen flow rate was $2.5 \mathrm{~mL} /$ min, while the rates for FID were fixed hydrogen $40 \mathrm{~mL} / \mathrm{min}$, nitrogen as makeup gas $40 \mathrm{~mL} / \mathrm{min}$, and air $250 \mathrm{~mL} / \mathrm{min}$.

\section{Analysis of the pharmaceutical preparations}

Five tablets of each pharmaceutical formulation, i.e. Brufen (Abbott Laboratories, Karachi), containing 200 mg/tablet ibuprofen; Ponstan (Pfizer Laboratories, Karachi), containing 25 mg/tablet mefenamic acid; and Qufen (High G. International, Karachi), containing $20 \mathrm{mg} /$ tablet diclofenac sodium, were ground to fine powder separately. The powder corresponding to 1 tablet was dissolved in methanol:water $(1: 1 \mathrm{v} / \mathrm{v})$. The solution was filtered and volume adjusted to $50 \mathrm{~mL}$. The solution $(0.2 \mathrm{~mL}$ and $0.4 \mathrm{~mL}$ ) after appropriate dilution was analyzed following the GC analytical procedure. Quantitation was achieved from the external calibration curve using a linear regression equation: $y=a x+b$.

\section{Analysis of the pharmaceutical preparations by standard addition}

Five tablets of each pharmaceutical formulation, Brufen, Ponstan, and Qufen, were processed for the analysis of the pharmaceutical preparations. After appropriate dilution, two solutions of $0.2 \mathrm{~mL}$ and $0.4 \mathrm{~mL}$ from each of the pharmaceutical preparations were obtained in duplicate. To a solution was added $0.5 \mathrm{~mL}$ of standard drug solution containing $10 \mu \mathrm{g} / \mathrm{mL}$. All the solutions were processed by GC analytical procedure. The quantitation was done from the linear regression equation and from the increase in response (peak height/peak area) with added standard.

\section{Analysis of biological samples}

Blood and urine samples were collected from healthy volunteers (students and employees) at the Institute of Advanced Research Studies in Chemical Sciences, University of Sindh. The blood samples were collected by vein puncture in ethylenediamine tetraacetic acid tubes and urine samples were collected in clean plastic bottles. The samples were processed as received. The volunteers were informed of the objective of the work and they gave verbal permission for their samples to be collected.

Each $(5 \mathrm{~mL})$ sample was kept at room temperature $\left(30{ }^{\circ} \mathrm{C}\right)$ for $30 \mathrm{~min}$ and was centrifuged at $4000 \mathrm{rpm}$ for $20 \mathrm{~min}$. The supernatant layer was collected and $5 \mathrm{~mL}$ of methanol was added. The contents were mixed well and again centrifuged for $20 \mathrm{~min}$ at $4000 \mathrm{rpm}$. The two solutions of supernatant $(1 \mathrm{~mL}$ each) were taken and a solution $0.5 \mathrm{~mL}$ of standard solution of ibuprofen, mefenamic acid, or diclofenac sodium was added containing $10 \mu \mathrm{g} / \mathrm{mL}$. The solutions were processed by GC analytical procedure. The quantitation was done from the linear regression equation of the external calibration curve. The solution without addition of the standard was treated as blank. 


\section{RESULTS AND DISCUSSION}

Spectrophotometric study without and with derivatization of ibuprofen

The solution of ibuprofen standard was examined on a double beam spectrophotometer within the range of $200-500 \mathrm{~nm}$. The absorbance was measured at an interval of $5 \mathrm{~nm}$. The absorption spectra were obtained with and without derivatization, which indicates the maximum absorbance at $260 \mathrm{~nm}$ for ibuprofen without derivatization when measured against the blank (methanol), while the absorption spectra after derivatization were obtained, which indicated maximum absorbance at 350 $\mathrm{nm}$ for ibuprofen (Figures 1a and 1b).

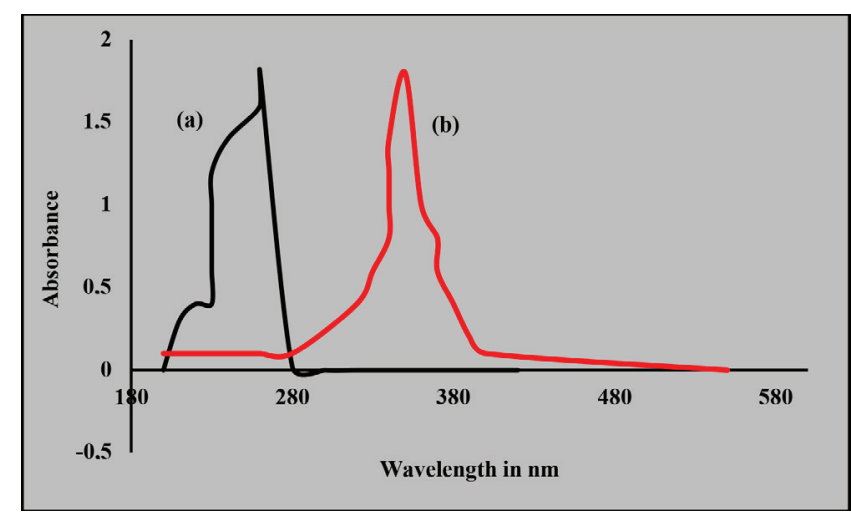

Figure 1. The absorption spectrum (a) shows ibuprofen without derivatization with a concentration of $10 \mu \mathrm{g} / \mathrm{mL}$ in methanol. The absorbance was measured within $200-500 \mathrm{~nm}$ (b) after derivatization ECF at a concentration of $10 \mu \mathrm{g} / \mathrm{mL}$ in methanol

ECF: Ethyl chloroformate

Spectrophotometric study without and with derivatization of mefenamic acid

The mefenamic acid in methanol standards was examined on a double beam spectrophotometer within the range of 200-500 nm. The absorption spectrum was obtained, which indicated maximum absorbance at $300 \mathrm{~nm}$ for mefenamic acid without derivatization when recorded against the reagent blank (methanol) (Figure 2a). The solution of mefenamic acid standard was also examined after derivatization with ECF within the range of 200-500 nm. The solution of mefenamic acid indicated maximum absorbance at $350 \mathrm{~nm}$ and was recorded against as the reagent blank (Figure $2 \mathrm{~b}$ ).

\section{Spectrometric study without and with derivatization of diclofenac sodium}

The diclofenac sodium solution in methanol was examined on a double beam spectrophotometer. The absorption spectra was obtained, which indicated maximum absorbance at 240 $\mathrm{nm}$ for diclofenac sodium when recorded against the blank (methanol) in Figure 3a, while the absorbance was measured after derivatization with ECF at $310 \mathrm{~nm}$ in Figure 3b.

\section{Effect of $\mathrm{pH}$}

The effect of $\mathrm{pH}$ on the derivatization of ibuprofen, mefenamic acid, and diclofenac sodium was analyzed within

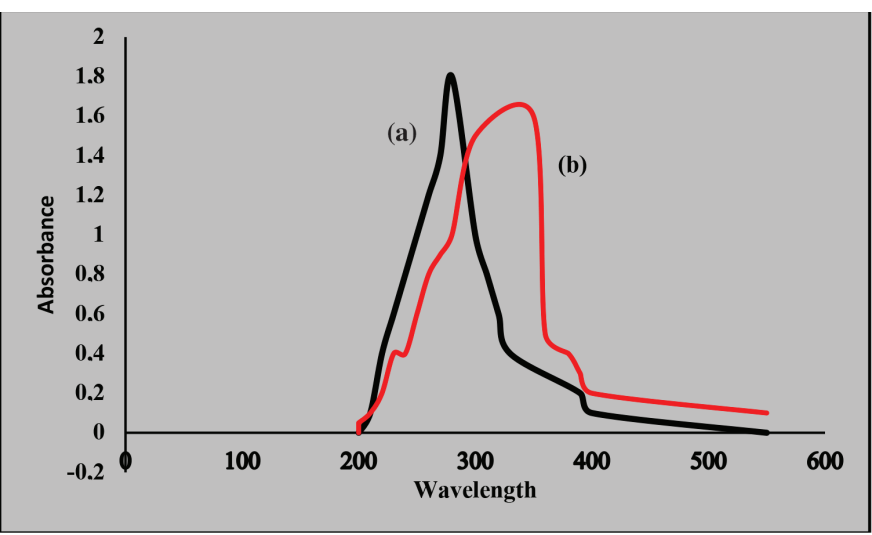

Figure 2. The absorption spectrum (a) shows mefenamic acid without derivatization with a concentration $10 \mu \mathrm{g} / \mathrm{mL}$ in methanol. The spectrum (b) is absorption spectrum of mefenamic acid after derivatization with an ECF concentration of $10 \mu \mathrm{g} / \mathrm{mL}$ in methanol

ECF: Ethyl chloroformate

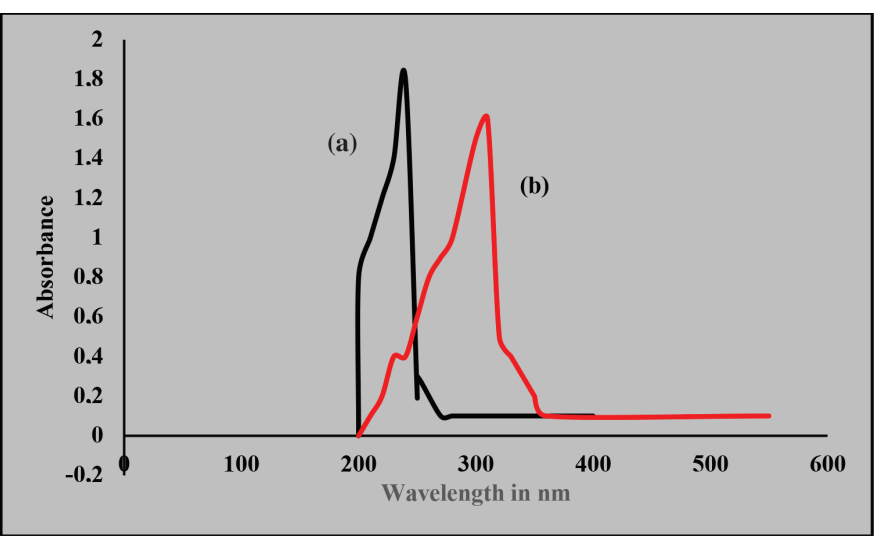

Figure 3. The absorption spectrum (a) of diclofenac sodium without derivatization at a concentration of $10 \mu \mathrm{g} / \mathrm{mL}$ in methanol. Spectrum (b) is after derivatization with ECF at a concentration of $10 \mu \mathrm{g} / \mathrm{mL}$ in methanol ECF: Ethyl chloroformate

the $\mathrm{pH}$ range of $1-10$. The reactions were monitored on a spectrophotometer against the reagent blank at appropriate $\mathrm{pH}$. The absorbance was measured at the wavelength of maximum absorbance at $350 \mathrm{~nm}$ for ibuprofen and mefenamic acid, while diclofenac sodium showed absorbance at 310 $\mathrm{nm}$. The maximum absorbance was observed at $\mathrm{pH} 9$ for ibuprofen, mefenamic acid, and diclofenac sodium as shown in Figure 4.

\section{Effect of ECF on derivatization}

The effect of change in concentration of the derivatization reagent ECF was examined between 0.1 and $0.5 \mathrm{~mL}$ at an interval of $0.1 \mathrm{~mL}$ following the analytical procedure. Absorbance was measured at the wavelength of maximum absorbance at 350 $\mathrm{nm}$ for ibuprofen and mefenamic acid, while diclofenac sodium showed absorbance at $310 \mathrm{~nm}$. The effect of concentration was not critical and a similar response was obtained from 0.2 to $0.5 \mathrm{~mL}$, but for a quick response $0.4 \mathrm{~mL}$ was selected. The solvent system acetonitrile:water:pyridine:methanol (8:42:8:42 $\mathrm{v} / \mathrm{v})(0.5 \mathrm{~mL})$ and carbonate buffer solution $\mathrm{pH} 9(0.5 \mathrm{~mL})$ were added during derivatization as mentioned in Figure 5. 


\section{Effect of sonication time on derivatization}

The effect of sonication time on the derivatization of ibuprofen, mefenamic acid, and diclofenac sodium with ECF were examined within 5 to $30 \mathrm{~min}$ at an interval of $5 \mathrm{~min}$ from the absorbance of the analyte as shown in Figure 6. Following the analytical procedure, the absorbance was measured at $350 \mathrm{~nm}$ for ibuprofen and mefenamic acid and $310 \mathrm{~nm}$ for diclofenac sodium. The sonication time was critical and the same response was obtained from 5 to $30 \mathrm{~min}$, but to get reproducible results a sonication time of 20 min was selected. The solvent system acetonitrile:water:pyridine:methanol (8:42:8:42 v/v) $(0.5 \mathrm{~mL})$ and carbonate buffer solution $\mathrm{pH} 9(0.5 \mathrm{~mL})$ were added.

\section{Spectrophotometric calibration of ibuprofen with derivatization}

The standard solution of different concentrations of ibuprofen was measured for absorbance at $350 \mathrm{~nm}$. Linear calibration curves were obtained that obeyed Beer's law within the concentration range 20 to $160 \mu \mathrm{g} / \mathrm{mL}$ ibuprofen. The coefficient of determination $\left(R^{2}\right)$ of ibuprofen was 0.999. The molar absorptivity calculated for ibuprofen at $350 \mathrm{~nm}$ was $43.733 \mathrm{~L}$ $\mathrm{mol}-\mathrm{cm}^{-1}$. The linear regression equation obtained for ibuprofen was $y=0.007 x+0.152$.

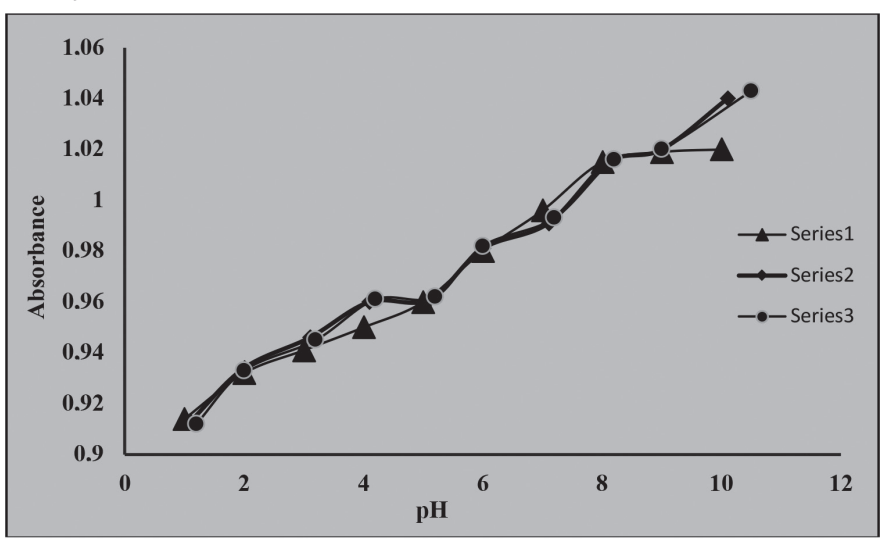

Figure 4. Effect of $\mathrm{pH}$ on the absorbance of ibuprofen, mefenamic acid, and diclofenac sodium derivative of ECF on a spectrophotometer at 350 and $310 \mathrm{~nm}$

ECF: Ethyl chloroformate

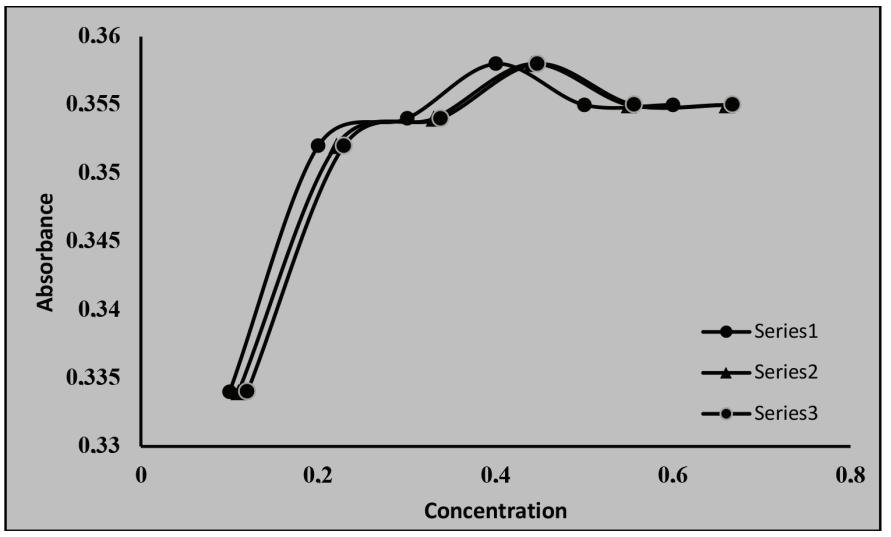

Figure 5. ECF concentration effect on the absorbance of ibuprofen, mefenamic acid, and diclofenac sodium

ECF: Ethyl chloroformate

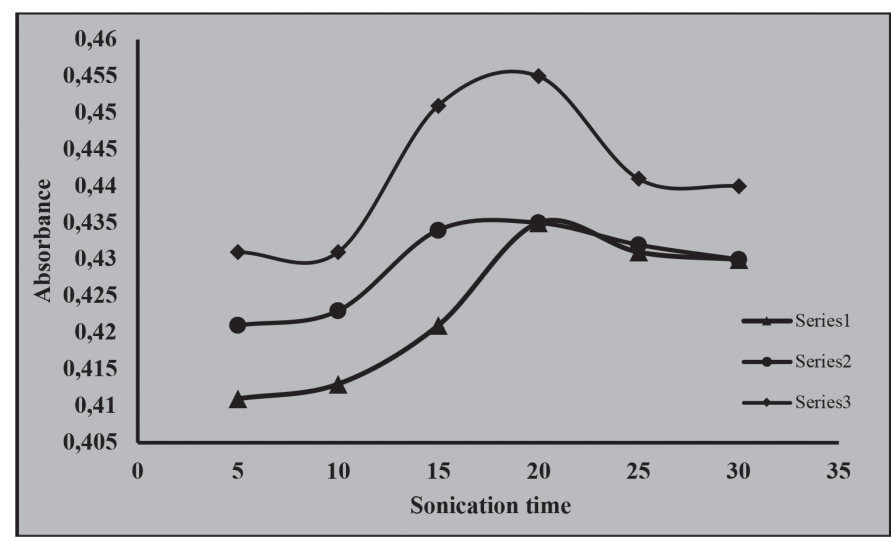

Figure 6. Effects of sonication time on the derivatization of ibuprofen, mefenamic acid, and diclofenac sodium

Spectrophotometric calibration of mefenamic acid with derivatization

The standard solution of different concentrations of mefenamic acid was measured for absorbance at $350 \mathrm{~nm}$ and linear calibration curves were obtained that obeyed Beer's law within the concentration range 10 to $200 \mu \mathrm{g} / \mathrm{mL}$ mefenamic acid. The coefficient of determination $\left(R^{2}\right)$ of mefenamic acid was 0.998 . The molar absorptivity calculated for mefenamic acid at $350 \mathrm{~nm}$

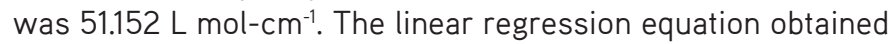
for mefenamic acid was $y=0.020 x+0.076$.

\section{Spectrophotometric calibration of diclofenac sodium with derivatization}

The standard solution of different concentration of diclofenac sodium was measured for the absorbance at $310 \mathrm{~nm}$ and linear calibration curves were obtained that obeyed Beer's law within the concentration range 20 to $160 \mu \mathrm{g} / \mathrm{mL}$ diclofenac sodium. The coefficient of determination $\left(R^{2}\right)$ of diclofenac sodium was 0.999. The molar absorptivity calculated for diclofenac sodium

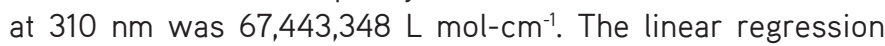
equation obtained for diclofenac sodium was $y=0.007 x+0.134$.

\section{Quantitation of NSAIDs by gas chromatography}

NSAIDs in GC elution occur after derivatization with ECF. Initially GC conditions were optimized for the elution as symmetrical peaks from the DB-1 column (30 $\mathrm{m} \times 0.32 \mathrm{~mm}$ id). Different temperature programs were examined with nitrogen flow rates and reasonable peak shapes were observed at initial column temperature at $150{ }^{\circ} \mathrm{C}$ for $3.0 \mathrm{~min}$, and with a heating rate of 20 ${ }^{\circ} \mathrm{C} / \mathrm{min}$ up to $280{ }^{\circ} \mathrm{C}$ and a hold time of $5.0 \mathrm{~min}$ with a total run time $13.2 \mathrm{~min}$ and the flow rate of nitrogen was adjusted to 2.5 $\mathrm{mL} / \mathrm{min}$.

Solution (0.2-1.0 mL) of $10 \mu \mathrm{g} / \mathrm{mL}$ stock solution was taken of each of ibuprofen, mefenamic acid, and diclofenac sodium and $0.5 \mathrm{~mL}$ of acetonitrile:water:pyridine:methanol (8:42:8:42 $\mathrm{v} / \mathrm{v} / \mathrm{v} / \mathrm{v}), 0.5 \mathrm{~mL}$ of sodium carbonate buffer solution ( $\mathrm{pH} 9)$, and $0.4 \mathrm{~mL}$ of ECF were added. The contents were sonicated for $20 \mathrm{~min}$ at $30{ }^{\circ} \mathrm{C}$ and $0.5 \mathrm{~mL}$ of chloroform was added. The mixture was shaken well, and a separatory funnel was used to separate the layers. A portion of the extract $(0.5 \mathrm{~mL}$ from 1 $\mathrm{mL}$ ) was transferred to a vial with a screw cap and $1 \mu \mathrm{L}$ of the solution was injected into the GC apparatus. 


\section{Quantitation of ibuprofen after derivatization}

The linear calibration curve of ibuprofen was obtained by plotting concentration $(\mu \mathrm{g} / \mathrm{mL})$ of ibuprofen against peak height and was obtained within 2-10 $\mu \mathrm{g} / \mathrm{mL}$ with the coefficient of determination $\left(R^{2}=0.996\right)$. The linear regression equation was $y=0.980 x+1.789$. The LOD and LOQ were calculated with $3: 1$ and $10: 1$ signal to noise ratios as $0.6 \mu \mathrm{g} / \mathrm{mL}$ and $1.8 \mu \mathrm{g} / \mathrm{mL}$, respectively (Table 1 ).

\section{Quantitation of mefenamic acid after derivatization}

The linear calibration curve of mefenamic acid was obtained by plotting concentration $(\mu \mathrm{g} / \mathrm{mL})$ against peak height and was obtained within $2-10 \mu \mathrm{g} / \mathrm{mL}$ with the coefficient of determination $\left(R^{2}=0.998\right)$. The linear regression equation was $y=0.230 x-0.174$. The LOD and LOQ were calculated with 3:1 and 10:1 signal to noise ratios as $0.4 \mu \mathrm{g} / \mathrm{mL}$ and $1.2 \mu \mathrm{g} / \mathrm{mL}$, respectively (Table 1).

\section{Quantitation of diclofenac sodium after derivatization}

The linear calibration curve of diclofenac sodium was obtained by plotting concentration $(\mu \mathrm{g} / \mathrm{mL})$ against peak height and was obtained within 2-10 $\mu \mathrm{g} / \mathrm{mL}$ with the coefficient of determination $\left(R^{2}=0.999\right)$. The linear regression equation was $y=1.070 x-1.301$. The LOD and LOQ were calculated with 3:1 and 10:1 signal to noise ratios as $0.5 \mu \mathrm{g} / \mathrm{mL}$ and $1.5 \mu \mathrm{g} / \mathrm{mL}$, respectively (Table 1).

\section{GC analysis of ibuprofen}

GC of ibuprofen after derivatization with ECF was performed. The GC was carried out with a DB-1 column $(30 \mathrm{~m} \times 0.32 \mathrm{~mm}$ id). Temperatures were set at different values and the flow rate of nitrogen was examined and reasonable peak shapes were observed at column temperature initially set at $150^{\circ} \mathrm{C}$ for $3 \mathrm{~min}$, followed by a heating rate of $20^{\circ} \mathrm{C} / \mathrm{min}$ up to $280^{\circ} \mathrm{C}$ and a hold time of $5 \mathrm{~min}$ with a whole run time of $13.2 \mathrm{~min}$. The flow rate of nitrogen was adjusted to $2.5 \mathrm{~mL} / \mathrm{min}$.

\section{GC analysis of mefenamic acid}

GC of mefenamic acid after derivatization with ECF was performed. The column used was DB-1 ( $30 \mathrm{~m} \times 0.32 \mathrm{~mm}$ id). Temperatures were set and reasonable peak shapes were observed at column temperature initially set at $150{ }^{\circ} \mathrm{C}$ for $3 \mathrm{~min}$, followed by a heating rate of $20^{\circ} \mathrm{C} / \mathrm{min}$ up to $280^{\circ} \mathrm{C}$ and a hold time of $5 \mathrm{~min}$ with a whole run time of $13.2 \mathrm{~min}$. The flow rate of nitrogen was adjusted to $2.5 \mathrm{~mL} / \mathrm{min}$.

\section{GC analysis of diclofenac sodium}

GC of diclofenac sodium after derivatization with ECF was performed. The column used was DB-1 ( $30 \mathrm{~m} \times 0.32 \mathrm{~mm}$ id). Temperatures were set and reasonable peak shapes were observed at column temperature initially set at $150^{\circ} \mathrm{C}$ for $3 \mathrm{~min}$, followed by a heating rate of $20{ }^{\circ} \mathrm{C} / \mathrm{min}$ up to $280^{\circ} \mathrm{C}$ and a hold time of $5 \mathrm{~min}$ with a whole run time of $13.2 \mathrm{~min}$ The flow rate of nitrogen was adjusted to $2.5 \mathrm{~mL} / \mathrm{min}$.

GC separation of ibuprofen, mefenamic acid, and diclofenac sodium

Gas chromatographic separation of ibuprofen, mefenamic acid, and diclofenac sodium was carried out after derivatization with ECF. Initially the GC conditions were optimized for the elution as symmetrical peaks from the DB-1 column $(30 \mathrm{~m} \times 0.32 \mathrm{~mm}$ id). Temperature was set at different values and the flow rate of nitrogen was examined and reasonable peak shapes were observed at initial column temperature at $150{ }^{\circ} \mathrm{C}$ for $3.0 \mathrm{~min}$, followed by a heating rate of $20^{\circ} \mathrm{C} / \mathrm{min}$ up to $280^{\circ} \mathrm{C}$ and a hold time of $5.0 \mathrm{~min}$ with an entire run time of $13.2 \mathrm{~min}$. The flow rate of nitrogen was adjusted to $2.5 \mathrm{~mL} / \mathrm{min}$ (Figure 7).

Drug analysis of ibuprofen, mefenamic acid, and diclofenac sodium with derivatization

The method developed for the determination of ibuprofen, mefenamic acid, and diclofenac sodium after derivatization was applied for the analysis of the active ingredients in brufen (ibuprofen), ponstan (mefenamic acid), and qufen (diclofenac sodium) tablets. At least 5 tablets containing ibuprofen $200 \mathrm{mg} /$ tablet, mefenamic acid $250 \mathrm{mg} /$ tablet, and diclofenac sodium $20 \mathrm{mg} / \mathrm{tablet}$ were ground to a fine powder and dissolved in an appropriate amount in methanol. Then the solution was filtered and volume adjusted of $50 \mathrm{~mL}$ and an aliquot of solution after derivatization with ECF was injected into the DB-1 GC column (30 $\mathrm{m} \times 0.32 \mathrm{~mm}$ id) and eluted with mobile phase optimized for GC separation and detection of ibuprofen, mefenamic acid, and diclofenac sodium. The quantitation was done from the linear regression equation and the amounts of ibuprofen,

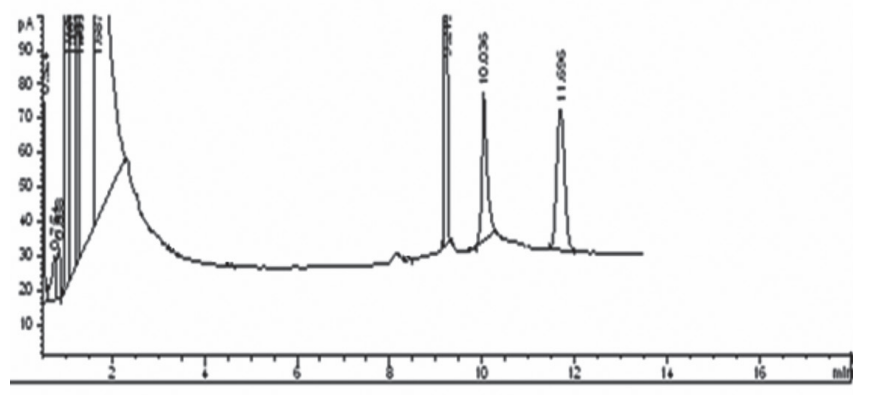

Figure 7. Gas chromatographic separation peaks of (1) ibuprofen, (2) mefenamic acid, and (3) diclofenac sodium after derivatization with ethyl chloroformate from a DB-1 column ( $30 \mathrm{~m} \times 0.32 \mathrm{~mm}$ id)

Table 1. Quantitation results of ibuprofen, mefenamic acid, and diclofenac sodium using ethyl chloroformate as derivatizing reagent

\begin{tabular}{llllll}
\hline Drug name & $\begin{array}{l}\text { Limits of } \\
\text { detection } \mu \mathrm{g} / \mathrm{mL}\end{array}$ & $\begin{array}{l}\text { Limits of quantitation } \\
\mu \mathrm{g} / \mathrm{mL}\end{array}$ & $\begin{array}{l}\text { Calibration range } \mu \mathrm{g} / \\
\mathrm{mL}\end{array}$ & $\begin{array}{l}\text { Coefficient of } \\
\text { determination }\left(R^{2}\right)\end{array}$ & Linear regression equation \\
\hline Ibuprofen & 0.6 & 1.8 & $2-10$ & 0.9965 & $\mathrm{y}=0.9809 \mathrm{x}+1.7892$ \\
\hline Mefenamic acid & 0.4 & 1.2 & $2-10$ & 0.998 & $\mathrm{y}=0.2303 \mathrm{x}-0.1743$ \\
\hline Diclofenac sodium & 0.5 & 1.5 & $2-10$ & 0.999 & $y=1.0705 \mathrm{x}-1.3018$ \\
\hline
\end{tabular}


mefenamic acid, and diclofenac sodium were found to be 156.93 $\mathrm{mg} / \mathrm{mL}, 193.14 \mathrm{mg} / \mathrm{mL}$, and $19.48 \mathrm{mg} / \mathrm{mL}$, respectively, which agreed with the amounts labeled, i.e. $160 \mathrm{mg} / \mathrm{mL}, 200 \mathrm{mg} / \mathrm{mL}$, and $20 \mathrm{mg} / \mathrm{mL}$, respectively. The \% error was calculated as $-1.9 \%,-3.4 \%$, and $-2.6 \%$. The RSD calculated from replicated analysis $(n=3)$ was within $0.5-3.0 \%$. The percentage recovery of ibuprofen, mefenamic acid, and diclofenac sodium was $98 \%$, $96 \%$, and $97 \%$, respectively (Table 2 ).

Determination of ibuprofen, mefenamic acid, and diclofenac sodium in spiked blood samples

Blood and urine samples ( $5 \mathrm{~mL}$ each) were collected from healthy volunteers on the condition that they had not taken any medicine over the previous week. The samples were centrifuged to remove blood cells and precipitate. The blood serum and urine were deprotonized with methanol. Samples $(1 \mathrm{~mL})$ were spiked with ibuprofen, mefenamic acid, and diclofenac sodium within the calibration range of each compound. The derivatization procedure with ECF was followed. The chloroform extract $(1 \mu \mathrm{L})$ was then injected into the gas chromatograph equipped with a DB-1 column ( $30 \mathrm{~m} \times 0.32 \mathrm{~mm}$ id). The elution was carried out under optimized conditions (Figures 8-13). The quantitation was done from the linear regression equation and all results are summarized in Tables 3 and 4.

\section{GC determination of ibuprofen with standard addition}

Five tablets of brufen (ibuprofen) containing $200 \mathrm{mg}$ were processed as described above. The solution $(0.2 \mathrm{~mL})$ was taken in duplicate. To a solution was added $0.2 \mathrm{~mL}$ of ibuprofen

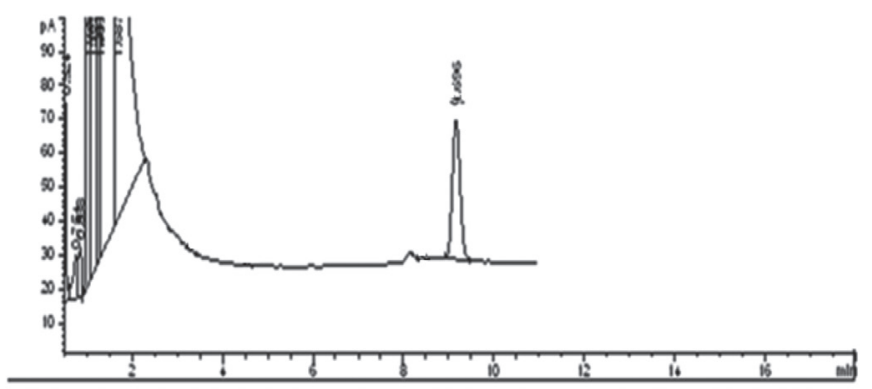

Figure 8. Gas chromatographic elution of ibuprofen in blood sample from a DB-1 column ( $30 \mathrm{~m} \times 0.32 \mathrm{~mm}$ id)

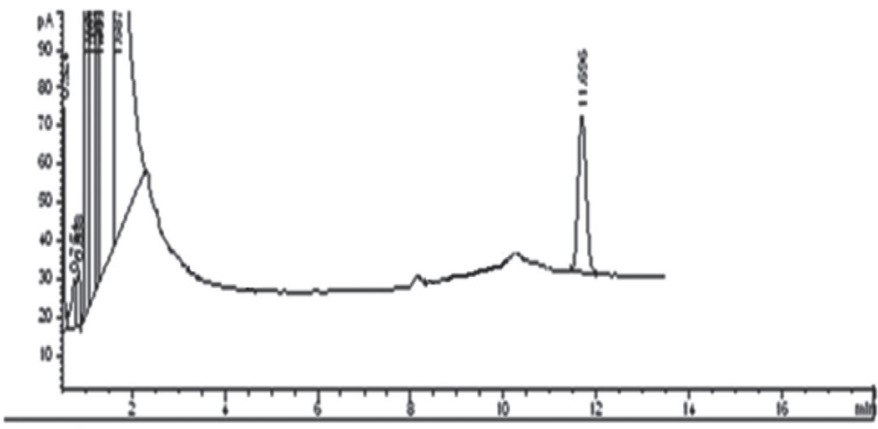

Figure 9. Gas chromatogram of mefenamic acid in blood sample from a DB-1 column ( $30 \mathrm{~m} \times 0.32 \mathrm{~mm}$ id) containing $14.16 \mu \mathrm{g}$ and both of the solutions were processed by GC. The quantitation was done from the linear regression equation of the external calibration curve and showed an increase in response with added standard (Table 5).

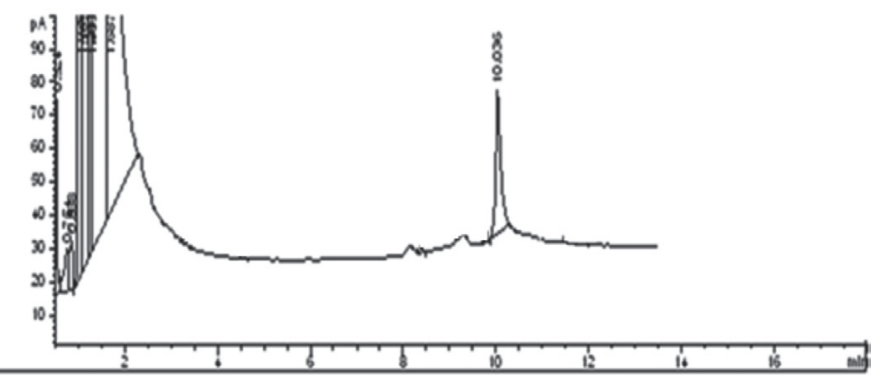

Figure 10. Gas chromatogram of diclofenac sodium in blood sample from a DB-1 column (30 m × $0.32 \mathrm{~mm}$ id)

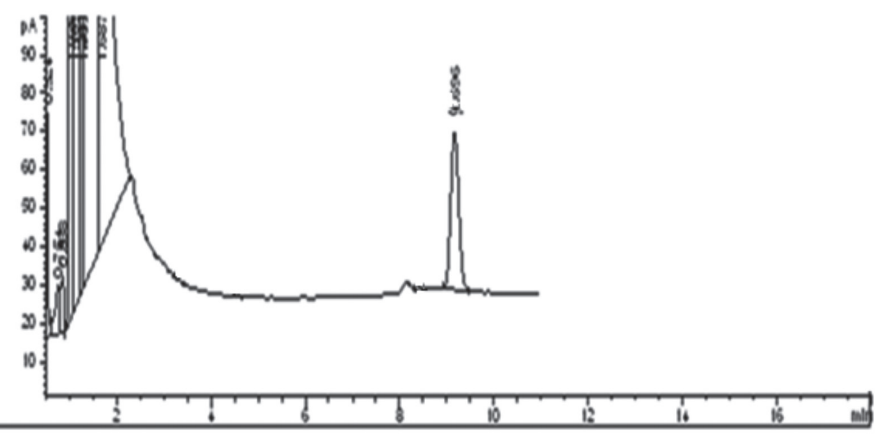

Figure 11. Gas chromatogram of mefenamic acid in urine sample from a DB-1 column (30 $\mathrm{m} \times 0.32 \mathrm{~mm}$ id)

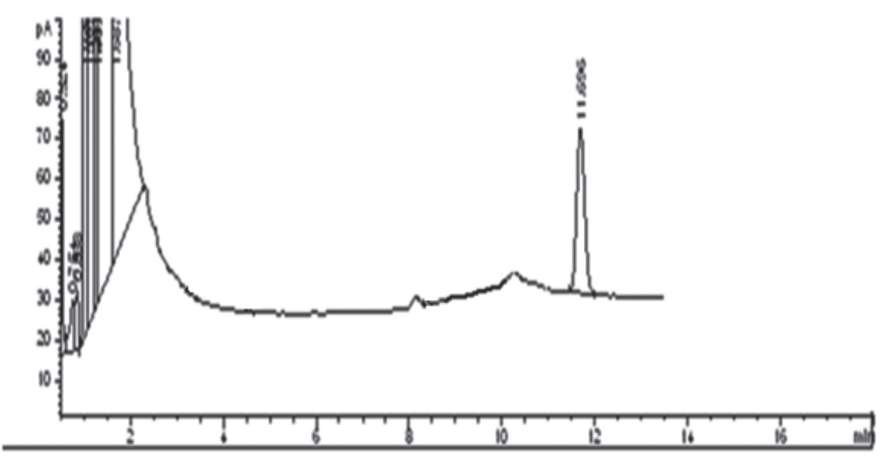

Figure 12. Gas chromatogram of mefenamic acid in urine sample from a DB-1 column (30 $\mathrm{m} \times 0.32 \mathrm{~mm}$ id)

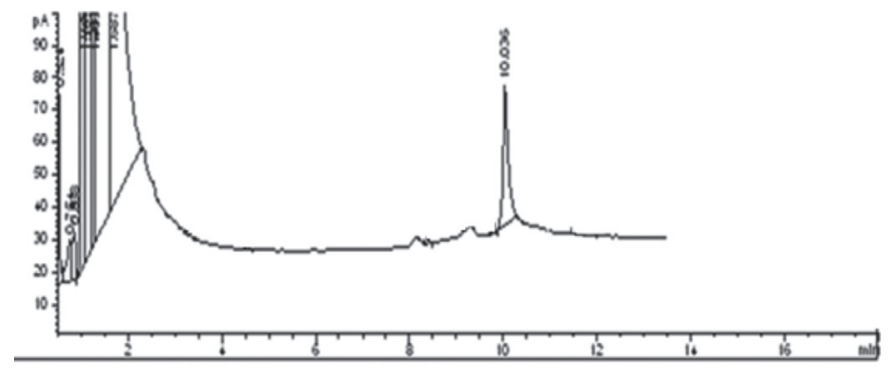

Figure 13. Gas chromatogram of diclofenac sodium in urine sample from a DB-1 column ( $30 \mathrm{~m} \times 0.32 \mathrm{~mm}$ id) 


\section{GC determination of mefenamic acid with standard addition}

Five tablet of ponstan (mefenamic acid) containing $250 \mathrm{mg}$ were processed as described above. The solution $(0.2 \mathrm{~mL})$ was taken in duplicate. To a solution was added $0.2 \mathrm{~mL}$ of ibuprofen containing $17.76 \mu \mathrm{g}$ and both solutions were processed by GC. The quantitation was done from the linear regression equation of the external calibration curve and showed an increase in response with added standard (Table 5).

GC determination of diclofenac sodium with standard addition Five tablets of qufen (diclofenac sodium) containing $20 \mathrm{mg}$ were processed as described above. The solution $(0.2 \mathrm{~mL})$ was taken in duplicate. To a solution was added $0.2 \mathrm{~mL}$ of ibuprofen containing $17.76 \mu \mathrm{g}$ and both of the solutions were processed by GC. The quantitation was done from the linear regression equation of the external calibration curve and showed an increase in response with added standard (Table 5).

Intraday and interday studies

Inter- and intraday assays were performed by analyzing replicate injections of standard solution to study the repeatability of the method. The intraassay precision $(n=5)$ was determined by the same analyst on the same day and under the same conditions with an interval of $2 h$, whereas the interassay precision $(n=3)$ was determined by the same analyst and under the same conditions on three consecutive days. The reproducibility of the separation was examined for all analytes in terms of peak area and the \% RSD values of each are shown in Table 6.

\section{CONCLUSION}

A new analytical procedure has been developed for the gas chromatographic and spectrophotometric determination of ibuprofen, mefenamic acid, and diclofenac sodium after derivatization with ECF. The LOD and LOQ of ibuprofen were calculated with 3:1 and 10:1 signal to noise ratio as $0.6 \mu \mathrm{g} /$ $\mathrm{mL}$ and $1.8 \mu \mathrm{g} / \mathrm{mL}$, for mefenamic acid as $0.4 \mu \mathrm{g} / \mathrm{mL}$ and $1.2 \mu \mathrm{g} / \mathrm{mL}$, and for diclofenac sodium as $0.5 \mu \mathrm{g} / \mathrm{mL}$ and $1.5 \mu \mathrm{g} / \mathrm{mL}$, respectively. The method is repeatable and has been successfully applied for the analysis of pharmaceutical preparations and spiked deproteinized serum and urine samples.

Table 2. Drug analysis of ibuprofen, mefenamic acid, and diclofenac sodium with derivatization

\begin{tabular}{llllllll} 
No & Name of standard & Name of tablet & Amount added $\mathrm{mg} / \mathrm{mL}$ & Amount found $\mathrm{mg} / \mathrm{mL}$ & Error $\%$ & RSD $\%$ & Recovery $\%$ \\
\hline 1 & Ibuprofen & Brufen & $200 \mathrm{mg} / \mathrm{mL}$ & $157.96 \mathrm{mg} / \mathrm{mL}$ & $-1.9 \%$ & $0.5 \%$ & $98 \%$ \\
\hline 2 & Mefenamic acid & Ponstan & $250 \mathrm{mg} / \mathrm{mL}$ & $193.14 \mathrm{mg} / \mathrm{mL}$ & $-3.4 \%$ & $3.6 \%$ & $96 \%$ \\
\hline 3 & Diclofenac sodium & Qufen & $20 \mathrm{mg} / \mathrm{mL}$ & $19.48 \mathrm{mg} / \mathrm{mL}$ & $-2.6 \%$ & $3.9 \%$ & $97 \%$ \\
\hline
\end{tabular}

RSD: Relative standard deviation

Table 3. Gas chromatographic analysis results of ibuprofen, mefenamic acid and diclofenac sodium in blood samples using ethyl chloroformate

\begin{tabular}{|c|c|c|c|c|c|c|}
\hline No & Age/gender & Name of standard & Amount added $\mu \mathrm{g} / \mathrm{mL}$ & Amount found $\mu \mathrm{g} / \mathrm{mL}$ & Error \% & Recovery \% \\
\hline 1 & $25 / F$ & Ibuprofen & $50 \mu \mathrm{g} / \mathrm{mL}$ & $49.04 \mu \mathrm{g} / \mathrm{mL}$ & -1.95 & $98 \%$ \\
\hline 2 & $25 / F$ & Mefenamic acid & $40 \mu \mathrm{g} / \mathrm{mL}$ & $39.66 \mu \mathrm{g} / \mathrm{mL}$ & -0.8 & $99 \%$ \\
\hline 3 & $25 / F$ & Diclofenac sodium & $50 \mu \mathrm{g} / \mathrm{mL}$ & $49.0 \mu \mathrm{g} / \mathrm{mL}$ & -0.8 & $99 \%$ \\
\hline
\end{tabular}

F: Female

Table 4. Gas chromatographic analysis results of ibuprofen, mefenamic acid, and diclofenac sodium in urine samples using ethyl chloroformate

\begin{tabular}{|c|c|c|c|c|c|c|}
\hline No & Age/gender & Name of standard & Amount added $\mu \mathrm{g} / \mathrm{mL}$ & Amount found $\mu \mathrm{g} / \mathrm{mL}$ & Error \% & Recovery \% \\
\hline 1 & $25 / F$ & Ibuprofen & $60 \mu \mathrm{g} / \mathrm{mL}$ & $59.14 \mu \mathrm{g} / \mathrm{mL}$ & 1.45 & $98 \%$ \\
\hline 2 & $25 / \mathrm{F}$ & Mefenamic acid & $50 \mu \mathrm{g} / \mathrm{mL}$ & $48.36 \mu \mathrm{g} / \mathrm{mL}$ & -2.9 & $98 \%$ \\
\hline
\end{tabular}

Table 5. Gas chromatographic standard addition of ibuprofen, mefenamic acid, and diclofenac sodium

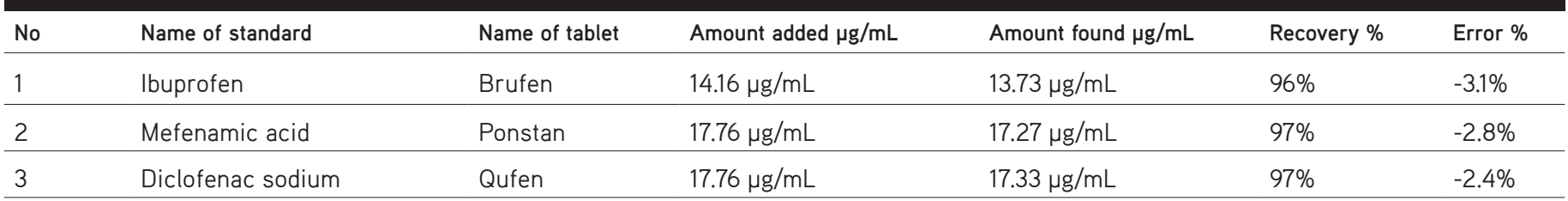


Table 6. Intraday and interday study of nonsteroidal anti-inflammatory drugs

Concentration $10(\mu \mathrm{g} / \mathrm{mL})$

\begin{tabular}{lllll}
\hline Ibuprofen & Peak area & RSD \% & Peak area & RSD \% \\
\hline 1 & 0.01644 & 0.33772 & 0.015473 & 0.362192 \\
\hline 3 & 0.0399 & 0.1564 & 0.02957 & 0.224109 \\
\hline
\end{tabular}

Mefenamic acid

\begin{tabular}{|c|c|c|c|c|}
\hline 1 & 0.01511 & 0.21487 & 0.01511 & 0.214868 \\
\hline 3 & 0.08417 & 0.05524 & 0.084167 & 0.055236 \\
\hline \multicolumn{5}{|c|}{ Diclofenac sodium } \\
\hline 1 & 0.02126 & 0.57062 & 0.019605 & 0.60538 \\
\hline
\end{tabular}

RSD: Relative standard deviation

Conflicts of interest: No conflict of interest was declared by the authors. The authors alone are responsible for the content and writing of the paper.

\section{REFERENCES}

1. Bazregar M, Rajabi M, Yamini Y, Asghari A, Hemmati M. Tandem airagitated liquid-liquid microextraction as an efficient method for determination of acidic drugs in complicated matrices. Anal Chim Acta. 2016;917:44-52.

2. Li N, Chen J, Shi YP. Magnetic polyethyleneimine functionalized reduced graphene oxide as a novel magnetic sorbent for the separation of polar non-steroidal anti-inflammatory drugs in waters. Talanta. 2019;191:526534.

3. Borghi SM, Fattori V, Ruiz-Miyazawa K, Bertozzi W, Lourenco-Gonzalez Y, Tatakihara RL, Bussmann AJC, Mazzuco TL, Casagrande R, Verri WA Jr. Pyrrolidine dithiocarbamate inhibits mouse acute kidney injury induced by diclofenac by targeting oxidative damage, cytokines and NFкB activity. Life Sci. 2018;208:221-231.

4. Davies NM, Anderson KE. Clinical pharmacokinetics of diclofenac. Clin Pharmacokinet. 1997;33:184-213.

5. Boynton CS, Dick CF, Mayor GH. NSAIDs: an overview. J Clin Pharmacol. 1988;28:512-517.

6. Fatta D, Achilleos A, Nikolaou A, Meric S. Analytical methods for tracing pharmaceutical residues in water and wastewater. Trends Anal Chem. 2007;26:515-533.

7. Sena MM, Chaudhry ZF, Collins CH, Poppi RJ. Direct determination of diclofenac in pharmaceutical formulations containing $B$ vitamins by using UV spectrophotometry and partial least squares regression. J Pharm Biomed Anal. 2004;36:743-749.

8. Carreira L, Rizk M, El-Shabrawy Y, Zakhari N, Toubar S. Europium (III) ion probe spectrofluorometric determination of diclofenac sodium. J Pharm Biomed Anal. 1995;13:1331-1337.

9. Thongchai W, Liawruangrath B, Thongpoon C, Machan T. High performance thin layer chromatographic method for the determination of diclofenac sodium in pharmaceutical formulations. Chiang Mai J Sci. 2006;33:123-128.

10. Schneider W, Degen P. Simultaneous determination of diclofenac sodium and its hydroxy metabolites by capillary column gas chromatography with electron-capture detection. J. Chromatogr. 1981;217:263-271.

11. Dinç E, Yücesoy C, Onur F. Simultaneous spectrophotometric determination of mefenamic acid and paracetamol in a pharmaceutical preparation using ratio spectra derivative spectrophotometry and chemometric methods. J Pharm Biomed Anal. 2002;28:1091-1100.

12. Ruiz TP, Lozano CM, Tomás V, Carpena J. Analysis of binary mixtures of flufenamic, meclofenamic and mefenamic acids by derivative synchronous fluorescence spectrometry. Talanta. 1998;47:537-545.

13. Ahrer W, Scherwenk E, Buchberger W. Determination of drug residues in water by the combination of liquid chromatography or capillary electrophoresis with electrospray mass spectrometry. J Chromatogr. 2001;910:69-78.

14. Singh AK, Jang Y, Mishra U, Granley K. Simultaneous analysis of flunixin, naproxen, ethacrynic acid, indomethacin, phenylbutazone, mefenamic acid and thiosalicycic acid in plasma and urine by high-performance liquid chromatography and gas chromatography-mass spectrometry. J. Chromatogr. 1991;568:351-361.

15. Sun Y, Takaba K, Kido H, Nakashima MN, Nakashima K. Simultaneous determination of arylpropionic acidic non-steroidal anti-inflammatory drugs in pharmaceutical formulations and human plasma by HPLC with UV detection. J Pharm Biomed Anal. 2003;30:1611-1619.

16. Quintana, JB, Carpinteiro J, Rodríguez I. Chapter 2.5 Analysis of acidic drugs by gas chromatography. Trends Anal Chem. 2007;50:185-218.

17. Orata F. Derivatization reactions and reagents for gas chromatography analysis. In Advanced Gas Chromatography-Progress in Agricultural, Biomedical and Industrial Applications, In Tech: 2012.

18. Halket, J. M.; Zaikin, V. G., Derivatization in mass spectrometry-1. Silylation. Eur J Mass Spectrom. 2003;9:1-21.

19. Zaikin VG, Halket JM. Derivatization in mass spectrometry-2. Acylation. Eur J Mass Spectrom. 2003;9:421-434. 